\title{
LIST OF MANUSCRIPTS
}

\section{The Elmer Belt Library of Vinciana}

35 Leonardo da Vinci, Trattato della pittura, Italy, 1582, in Italian

65 Michelangelo Buonarroti, Ricordo, Italy, 1533

66 Pietro da Vinci, notarized deed, Italy, 1459

67 Petrus de Crescentiis, Ruralium commodorum libri, Italy, 1466

68 “Raffaello Sanzio," forgeries, Italy(?), s. XIX(?)

70 Bartolomeo Ammannati, letter, Italy, 1570

73 Breviary, s. XVIII/XIX(?)

The Louise M. Darling Biomedical Library: History and Special Collections Division

Benjamin 1 Medical miscellany, Italy, s. XV²

3 Bernard of Gordon, fragment, France, s. XIV'

4 Conoximent de las orines, Libre de reseptes, Catalonia, 1466, in Catalan

5 Recipes, Germany, s. XV ${ }^{\text {med }}$, in German

8 Sebastian Jäger, Artzney Buech, Austria, 1580, in German

9 Medical miscellany, Germany, s. XV ${ }^{\text {med }}$, in German

10 Medical miscellany, Czechoslovakia, s. XV ${ }^{\text {med }}$, partly in Czech

11 Medical miscellany, Germany, s. XV ${ }^{\text {med }}$, partly in German

12 Medical miscellany, Italy, s. XV', partly in Italian

13 Medical and scientific miscellany, Italy, s. XV'

WZ240/P719L/1553/Rare Liber amicorum, Germany, s. XVI ${ }^{\text {med }}$

The John E. Anderson Graduate School of Management Library

Gross 1 Statutes of a mercantile court, Italy, 1577, in Italian

2 Business arithmetic, Italy, s. XVI ${ }^{2}$, in Italian

3 Della Stufa account book, Italy, 1581-1590, in Italian

4 Commercial treatises, England, s. XVI ${ }^{2}$

1 leaf

\section{The Music Library}

Hathaway 1-24 24 fragments of music, s. XI-XV 


\section{The University Research Library: Department of Special Collections}

100 bx 30 Letters, Germany, s. XVI

100 bx 102 Francesco Maria Della Rovere, letter, Italy, 1522, in Italian

$100 \mathrm{bx} \mathrm{113/4}$ Delfino charters and cartulary, Italy, s. XIII-XVII

$100 \mathrm{bx} 178$ Letters, etc., Italy and Spain, s. XIV² and XVI ${ }^{2}$

170/ 15 Francesco Berni, Life of Pietro Aretino, Italy, s. XVI², in Italian

$170 / 20$ Breviary, Flanders, s. XVI in

170/ 21 Nicholaus Cusanus, De visione dei, Germany, s. XV²

170/ 22 Pseudo Augustine, sermons, Italy, s. XV'

170/ 26 Book of hours, France, s. XVI in

170/ 43 Martyrology, Italy, s. XV'

170/ 49 Breviary, Paris, s. XV med

170/ 50 Book of hours, France, s. XV'

170/ 55 Handbook of chronology, France, s. XVI ${ }^{2}$

*170/ 84 Life of Jesus, France, s. XV ${ }^{2}$, in French

170/ 87 Medical notebook, Italy, s. XVII, in Italian

170/199 Jacobus de Voragine, Legenda aurea, France, s. XV med

*170/281 Life of Cosimo I de' Medici, Italy, 1574/1587, in Italian

*170/282 Carlo de' Medici, account book, Italy, 1535-1536

*170/292 Tristano Caracciolo, works, Italy, s. XVII

170/307 Ordinances of the Confraternity of St. Julian in Teruel, Spain, 1440-1574, in Spanish

*170/322 Paul of Venice, Summa naturalium, Italy, 1421

170/323 Inventory of the library of Antoine IV Ebrard de Saint-Sulpice, bishop of Cahors, France, 1589, in French

170/331 Stephen Langton, Interpretations of Hebrew names, England or France, s. XIII med

170/348 Bible, Spain, s. XIII ${ }^{\text {med }}$

170/358 Engineer's sketchbook, Italy, s. XVI ${ }^{2}$, and France, s. XVII ${ }^{2}$

*170/380 Venetian ambassadors' reports, papal conclaves, Italy, s. XVI-XVII'

170/382 Jacobus de Voragine, sermons, Italy, s. XIV²

170/442 Gregory the Great, Dialogues, Italy, s. XVex, in Italian

170/521 Antiphonal, Italy, s. XV'

-170/524 Rasis, Liber Almansoris, fragment, Italy, s. XIII²

170/525 Diego Hurtado de Mendoza, De la guerra de Granada, Spain, s. XVI-XVII, in Spanish

170/527 Missal and records of Uckerath, Germany, s. XII-XVI

170/529 Laurence Nowell, commonplace book, England, s. XVI med

902 Orsini family, archives, Italy, s. XIV-XX

952 bx 1 Giugni family, account book, Italy, 1580-1586

952 bx 2 Accounts, Italy, s. XVI-XVII

952 bx 3 Carlo di Andrea Cambini, account book, Italy, 1556-1616

952 bx 4 Biagio Castellani, notarial register, Italy, 1382-1391 


\section{LIST OF MANUSCRIPTS}

952 bx 5 Sienese fiscal records, Italy, 1601-1615

953 bx 1.3 Neapolitan miscellany, Italy, s. XVI

968 bx 1.71 Pierre Gautier, miscellany, France, 1572-1575

1033 Antiphonals, leaves, Italy or Spain, s. XVI

207016 dated documents, 1198-1585

**170/403 bx 1, 2 Collection of loose leaves, s. IX-XV 
